Human-Animal Relationships in Belief Narratives, BNN conference in the ISFNR interim conference Ragusa, June 2018

Koski, Kaarina

2018-11

Koski , K 2018 , ' Human-Animal Relationships in Belief Narratives, BNN conference in the ISFNR interim conference Ragusa, June 2018 ' , Fabula , vol. 59 , no. 3-4 , pp. 316-319 . https://doi.org/10.1515/fab

http://hdl.handle.net/10138/324469

https://doi.org/10.1515/fabula-2018-0108

unspecified

acceptedVersion

Downloaded from Helda, University of Helsinki institutional repository.

This is an electronic reprint of the original article.

This reprint may differ from the original in pagination and typographic detail.

Please cite the original version. 
Author's accepted manuscript

Published in Fabula 2018; 59 (3-4): 316-319.

Kaarina Koski:

\section{Human-Animal Relationships in Belief Narratives, BNN conference in the ISFNR interim conference Ragusa, June 2018}

The Belief Narrative Network functions within the ISFNR and brings together scholars of belief traditions from all over the world, publishes a newsletter four times a year and organizes conferences on belief narratives both within ISFNR conferences and independently (http://isfnr.org/belief-narrative-network.php).

In the ISFNR interim conference in Ragusa, BNN held a conference titled "Human-Animal Relationship in Belief Narratives". In eight sessions, the conference handled e.g. humananimal transformations, narrative expressions of sameness and otherness, respectful interspecies cooperation and diverse animals' roles in belief narratives and mythology. Here, I will outline some of the main themes which emerged in the conference.

\section{Human-animal transformations}

The symposium started with Terry Gunnell's introduction to human-animal transformation and particularly to Northern European narratives about human transformation into wolves and bears. The oldest Scandinavian traditions reflect an idea of an animal soul which enables the person to turn into an animal when needed, especially to fight fiercely in a battle. An animal skin too transforms the person wearing it. The raging warriors' legacy continues in the later times' belief narratives in which it is mostly men who transform.

In thirteenth and fourteenth century traditions, presented by Aðalheiður Guðmundsdóttir, the transformation into a wolf is involuntary and caused by deceitful women or magicians casting a spell. These wolves have a softer nature and long to return to their human form. Perceived as entertainment, these stories discuss the frightening unconscious within humans as well as men's beastly nature which can be aroused especially by women and war.

The natural environment determines the choice of animals which humans turn into. In India, they are many, such as snakes, tigers, dogs and fish. Margaret Lyngdoh described the Khasis' local weresnake tradition which contributes to the social control in village life. Desmond Kharmawphlang's paper was about men who have fish wives. Both these traditions are losing the natural habitat to which they belong, because of the pollution of water supplies in India. Neither fish nor hybrid or supernatural creatures can live in rivers which are full of plastic.

Transformations are described both in tales and in genres of everyday discourse. The narratives hint that humans and animals may not be very different after all. Transformation into an animal form can also be a punishment, a suspension from one's ordinary social role. But especially in European lore, the animal form or transformation often expresses otherness or refers to transgressions of social boundary. 


\section{Useful traditions and changing knowledge}

In belief traditions, humans turn either into animals proper or into monstrous hybrids. It is sometimes unclear if a person has turned into a wolf or a werewolf; similarly, what is meant by a werewolf - or a vampire - varies. The portrayal of the being may not be as important as the meanings of the transformation. Especially in times of social tension or insecurity, old traditions come true in people's own surroundings. In Anoop Vellani's presentation, vampire-like Yakshis emerged in local surroundings in connection with the administrative development of the Travancore area into a self-standing part of Kerala, India.

Mirjam Mencej linked contemporary Bosnia's werewolf stories into moral problems concerning ethnic and religious identities. In memorates from Bosnia, werewolf nowadays means an apparition or a ghost; especially a ghost of a person who has transgressed social norms or boundaries. Werewolf stories link to each other ethnic and religious otherness, exteriority, supernatural qualities, animalistic features and death. Werewolf is thus a polygon upon which people project their fears, anxieties, judgements and values. In Bosnian villages, interreligious marriages and unstable ethnic identities are among the factors that trigger the werewolf experiences right now. Social tensions make the traditions relevant. As one informant emphasised: this is not a story, this is true!

Belief is a term which we use as a label when we discuss traditions about the supernatural or the extraordinary. Nevertheless, belief narrative scholars generally acknowledge the status of the contents of many of these stories as knowledge: they are true to the narrators, no matter what outsiders think. In the discussion, Ülo Valk reminded that in global and historical perspective, it has been generally known that people can turn into animals. Considering this, we should perhaps wonder why we in the contemporary Western culture do NOT think it is possible. Sadhana Naithani suggested whether this has a causal connection with the fact that during the last two hundred years, a lot of species have become extinct. The increased attention towards animals in research reflects attempts to change the direction of this development.

\section{Return to the respectful human-animal cooperation}

It is a common motif of tales and myths all over the world that in earlier times, animals could talk and were equal with humans on earth. It is generally known that in certain shamanistic cultures, the shaman can have an animal-shaped helper spirits. In Western countries, there is even a stereotypical thought that indigenous people such as Native Americans all have contacts to spiritual animals. Reet Hiiemäe presented some new materials on contemporary Estonians' experiences on soul animals. The experiences and apparitions are quite similar to experiences of angels or Virgin Mary elsewhere; in this particular subculture, the relevant imagery comes from the Native Americans and shamanistic cultures via New Age spiritualism, literature and popular culture. The experiences have been personally meaningful and encouraging to the narrators who have got their own soul-animal.

In his presentation, Tok Thompson reminded that Christianity has promoted human dominance over non-human animals while indigenous traditions portray them more respectfully and give them agency. Natural sciences have shown that non-human animals have a greater mental and social capacity than we have used to think, and etologists rightly talk about animal culture and communication. Postcolonial and post-humanist approaches challenge us to reassess our relationship to the animal world. Thompson suggests that folklorists should prepare to collect and study the folklore of non-human animals as well, in cooperation with etologists. 
Respect towards non-human animals can cover all species, including insects like cockroaches. Posthumanist animal studies oppose speciesist cultural ideas such as taking for granted that insects should be killed. Suzana Marjanić contrasted pesticide advertisements with examples of Slavic traditions in favour of cockroaches as a sign of wealth and prosperity of the house. She also showed samples of modern art on the cockroach theme.

\section{Animals in myths and symbolic representations}

The conference offered a rich array of animal lore. The multiplicity of meanings given to each species often makes the relationship ambiguous. Fumihiko Kobayashi's paper on the Japanese stories about the mouse paradise portrayed the mouse as a symbol of wealth and discussed the human desire for wealth and fear of misfortune. The pattern had some similarity with Russian traditions of cockroach: the same animal both symbolises wealth and corrupts it. Ambiguous meanings were present in traditions concerning frogs, as well. Vita Džekčioriūtè-Medeišienè discussed frog's roles which range from a health-bringing animal to a dangerous creature in Lithuanian belief narratives. Jelka Vince Pallua presented the mythical frog's meanings especially in relation to fertility and female reproduction, which have also turned into negative and sinful in the Christian tradition. Both presentations witnessed the relevance of this animal in vernacular culture.

The diversity of the topics and approaches inevitably made the conference somewhat fragmentary. We had theoretically insightful papers as well as rich descriptions of various local traditions and historical developments. A possibility to discuss the input and draw some general remarks together at the end of the conference would have been valuable, but this time, our schedule did not allow it. However, I am sure that the participants have been able to construct connections between the topics and approaches on their own, as well.

The question of human animal relations is topical in the world right now, and beliefs, values, and narratives are a relevant part of it. It seems that in our contemporary societies, we have two competing belief narratives about the human-animal relations. They are the narrative of human dominance and the narrative of mutual respect and equality. It is a task of folklorists and belief narrative scholars to spread the awareness of these narratives. 